\title{
RELAKSASI BENSON UNTUK MENGONTROL KADAR GULA DARAH PENDERITA DM DI WILAYAH KERJA PUSKESMAS PAHANDUT PALANGKA RAYA
}

\author{
Benson Relaxation to Control Blood Sugar Levels in People with DM in the Pahandut \\ Palangka Raya Health Center Working Area
}

\section{Aida Kusnaningsih}

Poltekkes Kemenkes Palangka Raya, Palangka Raya,

Kalimantan Tengah, Indonesia

*email:

aidaparyanto@yahoo.co.id

\section{Kata Kunci:}

Diabetes Mellitus

Puskesmas

Relaksasi Benson

\section{Keywords:}

Diabetes Mellitus

Health Center

Benson Relaxation

\begin{abstract}
Abstrak
Diabetes Melitus merupakan penyakit metabolik yang ditandai dengan peningkatan kadar glukosa darah. Salah satu cara mengelolanya adalah dengan Relaksasi Benson. Relaksasi Benson merupakan suatu teknik relaksasi yang merupakan kombinasi teknik relaksasi dengan sistem keyakinan individu. Penelitian menunjukkan bahwa relaksasi Benson dapat menurunkan kadar glukosa darah pada penderita DM. Kegiatan pengabdian masyarakat dengan menerapkan hasil penelitian yaitu Relaksasi Benson untuk mengontrol kadar gula darah dilaksanakan pada 32 penderita DM. Kegiatan meliputi pendidikan kesehatan tentang DM dan Relaksasi Benson serta praktik melaksanakan Relakasi Benson diiringi alunan suara Asmaul Husna. Media yang digunakan selama kegiatan yaitu LCD proyektor dan IM3 Asmaul Husna. Kegiatan berjalan dengan lancar sesuai dengan rencana, semua peserta mengikuti kegiatan dengan antusias dari awal sampai akhir. Selama kegiatan berlangsung, media yang digunakan selama kegiatan dapat berfungsi dengan baik, dan lingkungan cukup kondusif. Hasil evaluasi peserta mampu menyebutkan kembali tentang DM dan penatalaksanaannya serta mampu mempraktikkan Relaksasi Benson dengan baik. Kegiatan memberikan manfaat dalam berupa peningkatan pengetahuan tentang Diabetes Melitus dan penatalaksanaannya serta kemampuan melaksanakan Relaksasi Benson untuk mengontrol kadar gula darah pada penderita DM di wilayah kerja Puskesmas Pahandut Palangka Raya.
\end{abstract}

\begin{abstract}
Diabetes mellitus is a metabolic disease characterized by an increase in blood glucose levels. One way to manage it is with Benson Relaxation. Benson Relaxation is a relaxation technique that is a combination of relaxation techniques with individual belief systems. Research shows that Benson relaxation can reduce blood glucose levels in DM patients. Community service activities by applying the results of the study namely Benson Relaxation to control blood sugar levels were carried out in 32 DM patients. Activities include health education about DM and Benson Relaxation and the practice of carrying out Benson's Relation accompanied by the sounds of the Asmaul Husna. The media used during the activity were LCD projector and IM3 Asmaul Husna. The event went smoothly according to the plan; all participants followed the movement enthusiastically from beginning to end. During the event, the media used during the activity can function properly, and the environment is quite conducive. The evaluation results of the participants were able to mention again about DM and its management and were able to practice Benson Relaxation well. The activity provided benefits in the form of increasing knowledge about Diabetes Mellitus and its management and the ability to carry out Benson Relaxation to control blood sugar levels in DM patients in the Pahandut Community Health Center Palangka Raya Benson work area.
\end{abstract}

(C) 2019 The Authors. Published by Institute for Research and Community Services Universitas Muhammadiyah Palangkaraya. This is Open Access article under the CC-BY-SA License (http://creativecommons.org/licenses/by-sa/4.0/). DOI: https://doi.org//0.33084/pengabdianmu.v4il.629.

\section{PENDAHULUAN}

Diabetes melitus (DM) merupakan penyakit metabolik yang ditandai oleh kenaikan kadar glukosa darah atau hiperglikemia, akibat kegagalan sekresi insulin dan atau penggunaan insulin dalam metabolisme tidak adekuat (Putri \& Isfandiari, 20l3). Jumlah pasien diabetes pada tahun 2015 di dunia sebesar 415 juta jiwa dan di Asia Tenggara sebesar 78,3 juta jiwa (IDF, 20I5). Angka kejadian DM berdasarkan penelitian epidemiologi 
menunjukkan adanya kecendrungan peningkatan baik di dunia maupun di Indonesia. Angka kejadian DM di dunia pada tahun 2013 sebesar 382 juta orang dan pada tahun 2035 jumlah tersebut akan meningkat menjadi 592 juta orang dan diperkirakan dari 382 juta orang tersebut 175 diantaranya belum terdiagnosis, sehingga terancam berkembang progresif menjadi komplikasi tanpa disadari dan tanpa pencegahan. Data lain yang dikemukan oleh badan kesehatan dunia (WHO) bahwa jumlah penderita DM di dunia tahun 2015 sebesar $4 I 5$ juta jiwa, dan pada tahun 2040 jumlah tersebut diperkirakan akan meningkat menjadi 642 juta jiwa (WHO, 2016).

Propinsi Kalimantan Tengah berada pada urutan kedua belas dari tiga puluh empat propinsi di Indonesia dengan proporsi penderita DM pada usia >I5 tahun. Angka kejadian DM di Propinsi Kalimantan Tengah pada tahun 2015 berada pada peringkat kelima dari sepuluh penyakit terbanyak dengan jumlah 5.I37 kasus (Dinas Kesehatan Provinsi Kalimantan Tengah, 20I5). Penyakit DM tidak/tanpa insulin berada pada urutan keempat belas dari sepuluh daftar penyakit di instalasi rawat jalan Rumah Sakit Umum Doris Sylvanus Palangka Raya dengan jumlah 4.108 kasus pada tahun 2016 (Badan Pusat Statistik Kalimantan Tengah, 2016).

DM apabila tidak ditangani dengan baik dapat berakibat buruk. Akibat yang akan terjadi dapat berupa kerusakan berbagai sistem tubuh terutama syaraf dan pembuluh darah, yaitu meningkatkan resiko penyakit jantung dan stroke, neuropati (kerusakan syaraf) di kaki yang meningkatkan kejadian ulkus kaki, retinopati diabetikum, gagal ginjal dan risiko kematian dua kali dibandingkan dengan bukan penderita DM (Wulandari \& Isfandiari, 2013).

Akibat buruk dari DM dapat dicegah dan diatasi dengan pengelolaan yang baik. Penelitian Kuswandi (2008) menunjukkan bahwa Relaksasi Benson dilakukan dua kali sehari selama tujuh hari, pada saat perut kosong berpengaruh terhadap penurunan kadar glukosa darah pada pasien DM tipe 2. Penelitian Purwasih (2017) menunjukkan bahwa Relaksasi Benson dan terapi murottal surat Ar-Rahmaan menurunkan kadar glukosa darah puasa pada penderita Diabetes Melitus Tipe 2 di Kecamatan Maos.

Relaksasi Benson merupakan suatu teknik relaksasi yang merupakan penggabungan antara teknik respon relaksasi dengan sistem keyakinan individu/faith factor (difokuskan pada ungkapan tertentu berupa nama-nama tuhan atau kata-kata yang memiliki makna menenangkan bagi pasien itu sendiri) diucapkan berulang-ulang dengan ritme yang teratur disertai sikap pasrah (Benson \& Proctor, 2000). Relaksasi Benson dapat menurunkan kadar gula darah pasien diabetes dengan menekan pengeluaran hormon-hormon yang dapat meningkatkan kadar gula darah, yaitu epinefrin, kortisol, glucagon, adrenocorticotropic hormone (ACTH), kortikosteroid, dan tiroid (Smeltzer \& Bare, 2002; Smeltzer et al., 2008).

Mekanisme penurunan kadar glukosa darah melalui relaksasi, yaitu dengan cara menekan pengeluaran epinefrin sehingga menghambat konversi glikogen menjadi glukosa, menekan pengeluaran kortisol dan menghambat metabolisme glukosa sehingga asam amino, laktat, dan pirufat tetap disimpan di hati dalam bentuk glikogen sebagai energi cadangan; menekan pengeluaran glukagon sehingga dapat mengkonversi glikogen dalam hati menjadi glukosa, menekan ACTH dan glukokortikoid pada korteks adrenal sehingga dapat menekan pembentukan glukosa baru oleh hati, di samping itu lipolysis dan katabolisme karbohidrat dapat ditekan, yang dapat menurunkan kadar glukosa darah (Smeltzer \& Bare, 2002; Smeltzer et al., 2008).

Hal tersebut di atas menunjukkan bahwa Relaksasi Benson dapat membantu penderita DM dalam mengontrol kadar gula darah. Perawat sebagai salah satu tenaga kesehatan yang professional perannya sangat diperlukan dalam membantu penderita DM untuk dapat meningkatkan kualitas hidupnya. Peran perawat dapat dilakukan dengan upaya promotif dan preventif dengan pemberian pendidikan kesehatan tentang Diabetes 
Melitus dan Relaksasi Benson untuk membantu penderita DM mengontrol kadar gula darahnya dan mencegah terjadinya komplikasi lebih lanjut.

\section{METODOLOGI}

Metode pelaksanaan kegiatan pengabdian masyarakat yang dilakukan adalah melalui pendidikan kesehatan tentang Diabetes melitus dan penatalaksanaannya, Relaksasi Benson untuk mengontrol kadar gula darah serta praktik pelaksanaan Relaksasi Benson pada penderita DM di Posyandu Lansia Eka Harapan Wilayah Kerja Puskesmas Pahandut Palangka Raya Kegiatan ini dilaksanakan pada bulan November tahun 2018.

Tujuan kegiatan pengabdian masyarakat adalah mengaplikasikah hasil penelitian mengenai Efektifitas Relaksasi Benson terhadap kadar gula darah penderita DM. Secara umum diharapkan setelah mengikuti kegiatan pengabdian masyarakat ini, peserta (penderita DM) menunjukkan peningkatan pengetahuan dan ketrampilan tentang diabetes melitus dan penatalaksanaannya. Secara khusus tujuan kegiatan adalah peserta memahami tentang penyakit diabetes melitus dan penatalaksanaannya salah satunya dengan Relaksasi Benson, peserta memahami dan mampu mempraktikkan cara melaksanakan Relaksasi Benson dalam mengontrol kadar gula darah.

Sasaran primer dari kegiatan pengabdian masyarakat ini adalah penderita diabetes melitus yang berkunjung dan merupakan anggota dari Posyandu Lansia Eka Harapan Wilayah Kerja Puskesmas Pahandut Palangka Raya berjumlah 32 orang. Sasaran sekunder adalah para kader posyandu lansia Eka Harapan Wilayah Kerja Puskesmas Pahandut Palangka Raya berjumlah 5 orang.

Ruang Lingkup kegiatan pengabdian masyarakat ini adalah upaya peningkatan kualitas hidup penderita diabetes melitus melalui kegiatan promotif dan preventif dengan pendidikan kesehatan tentang Diabetes Melitus dan penatalaksanaannya serta Relaksasi Benson dalam upaya untuk mengontrol kadar gula darah. Pendidikan kesehatan pada kegiatan pengabdian masyarakat ini dilaksanakan dengan menggunakan metode ceramah dan tanya jawab dengan menggunakan media LCD proyektor dan Leaflet. Praktik Relaksasi Benson dilaksanakan dengan menggunakan metode demonstrasi dengan menggunakan media Laptop, pengeras suara, dan MP3 “Asmaul Husna”.

Pelaksana kegiatan pengabdian masyarakat adalah tim yang terdiri atas dosen Poltekkes Kemenkes Palangka Raya, Clinical Instructor dari Puskesmas Pahandut dan Mahasiswa Program Studi Diploma IV Keperawatan berjumlah 13 orang. Masing-masing anggota tim mempunyai tugas yaitu sebagai edukator, fasilitator, observer, notulis, dokumentator.

\section{HASIL DAN PEMBAHASAN}

Kegiatan pengabdian masyarakat yang dilakukan oleh tim berjalan dengan baik dan mendapat respon yang positif dari peserta. Peserta yang hadir selama kegiatan berjumlah 37 orang yang terdiri atas 32 orang peserta adalah penderita DM dan 5 orang kader posyandu. Semua peserta mengikuti kegiatan dari awal sampai akhir.

Tahapan kegiatan yang dilakukan selama kegiatan pengabdian masyarakat adalah sebagai berikut:

I. Kegiatan diawali dan dibuka oleh MC kemudian dilanjutkan dengan sambutan ketua tim Pengabdian Masyarakat. Ketua Tim memperkenalkan diri dan anggota tim, menyampaikan maksud dan tujuan kegiatan, manfaat yang diperoleh dari kegiatan serta membuat kontrak waktu bersama dengan peserta.

2. Kegiatan selanjutnya adalah sambutan dari perwakilan Kader Posyandu, dan perkenalan serta penerimaan pihak posyandu terhadap kegiatan pengabdian masyarakat. 
3. Acara kemudian dilanjutkan dengan doa bersama. Setelah itu dilanjutkan dengan kegiatan senam pagi sebagai pembuka kegiatan.

4. Acara Puncak yaitu tim yang bertugas sebagai educator menyajikan materi pendidikan kesehatan tentang diabetes melitus dan Penatalaksanaannya, serta Relaksasi Benson untuk mengontrol gula darah

5. Setelah penyajian materi dilanjutkan dengan sesi tanya jawab dan diskusi terkait materi diabetes melitus dan penatalaksanaannya serta relaksasi Benson. Selama kegiatan diskusi berlangsung, anggota tim yang bertugas selaku fasilitator berperan aktif membantu dan memacu peserta untuk bertanya mengenai topik yang dibahas. Peserta yang hadir Selama kegiatan peserta aktif bertanya mengenai halhal yang kurang dipahami dan dimengerti.

6. Kegiatan kemudian dilanjutkan dengan praktik melakukan Relaksasi Benson. Kegiatan dipimpin oleh tim pelaksana sebagai pemadu gerak, diiringi dengan alunan musik/suara MP3 Asmaul Husna. Selama kegiatan praktik seluruh peserta mengikuti kegiatan dengan baik, dan mendapat respon yang baik dari peserta. Beberapa peserta mengatakan merasa lebih rilek dan nyaman setelah melaksanakan praktik relaksasi.

7. Setelah praktik Relaksasi Benson kegiatan dilanjutkan dengan pemeriksaan kadar gula darah sewaktu.

8. Sesi akhir dari kegiatan adalah evaluasi kegiatan secara keseluruhan. Kegiatan diakhiri dengan penyerahan bingkisan kepada semua peserta dan foto bersama.

Terapi Benson merupakan teknik relaksasi pernafasan dengan melibatkan keyakinan yang mengakibatkan penurunan terhadap konsumsi oksigen oleh tubuh dan otot-otot tubuh menjadi rileks sehingga menimbulkan perasaan tenang dan nyaman. Apabila $\mathrm{O}_{2}$ dalam otak tercukupi maka manusia dalam kondisi seimbang. Kondisi ini akan menimbulkan keadaan rileks secara umum pada manusia. Perasaan rileks akan diteruskan ke hipotalamus untuk menghasilkan conticothropin releaxing factor (CRF). CRF akan merangsang kelenjar dibawah otak untuk meningkatkan produksi proopiod melanocorthin (POMC) sehingga produksi enkephalin oleh medulla adrenal meningkat. Kelenjar dibawah otak juga menghasilkan $\beta$ (beta) endorphine sebagai neurotransmitter (Yusliana, 20I5).

Endorphine muncul dengan cara memisahkan diri dari deyoxyribo nucleid acid (DNA) yaitu substansi yang mengatur kehidupan sel dan memberikan perintah bagi sel untuk tumbuh atau berhenti tumbuh. Pada permukaan sel terutama sel saraf terdapat area yang menerima endorphine. Ketika endorphine terpisah dari DNA, endorphine membuat kehidupan dalam situasi normal menjadi tidak terasa menyakitkan. Endorphine mempengaruhi impuls nyeri dengan cara menekan pelepasan neurotransmitter di presinap atau menghambat impuls nyeri dipostsinap sehingga rangsangan nyeri tidak dapat mencapai kesadaran dan sensorik nyeri tidak dialami (Solehati \& Kokasih, 20I5).

Penelitian yang dilakukan oleh Datak (2008) mengenai Efektifitas Relaksasi Benson terhadap nyeri pascabedah pasien TUR prostat juga membuktikan bahwa relaksasi Benson efektif mengatasi nyeri dibandingkan hanya menggunakan terapi analgetik saja dengan $p$ value 0,019 $<\alpha(0,05)$. Penelitian Yusliana (2015) yang berjudul Efektivitas Relaksasi Benson terhadap penurunan nyeri pada lbu Post partum Sectio Caesarea dengan desain pretest and post-test with control group pada 30 responden yang dibagi dalam dua kelompok yaitu kontrol dan intervensi, dengan uji $\mathrm{t}$ independent didapatkan hasil mean skor nyeri pada kelompok intervensi adalah 2,867 dengan standard deviasi 0,4419, dan pada kelompok kontrol 3,767 dengan standard deviasi 0,5627 dan $P$ value $=0,000$ yang berarti bahwa pemberian Relakasi Benson efektif terhadap skor nyeri ibu postpartum sectio caesarea. Penelitian Rasubala (2017) pada 16 orang pasien post operasi appendiksitis dengan desain pre dan post test without control didapatkan 
hasil teknik Relaksasi Benson berpengaruh terhadap skala nyeri pada pasien post operasi apendiksitis $(P$ value $=0,000)$.

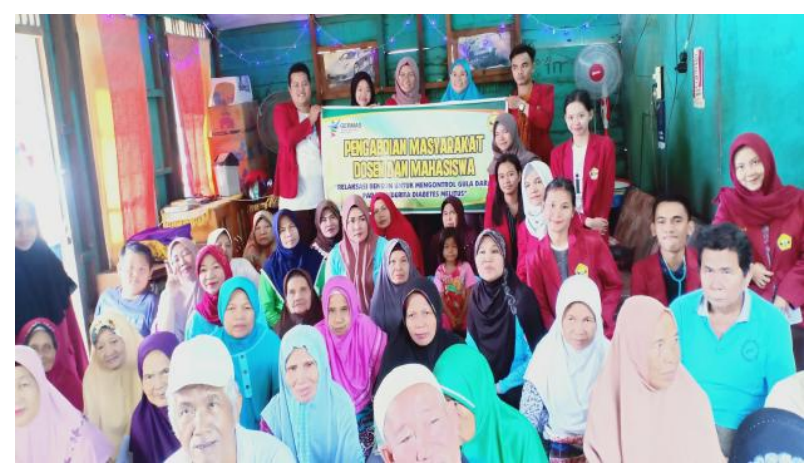

Gambar I. Peserta dan Pelaksana Pengabdian Masyarakat

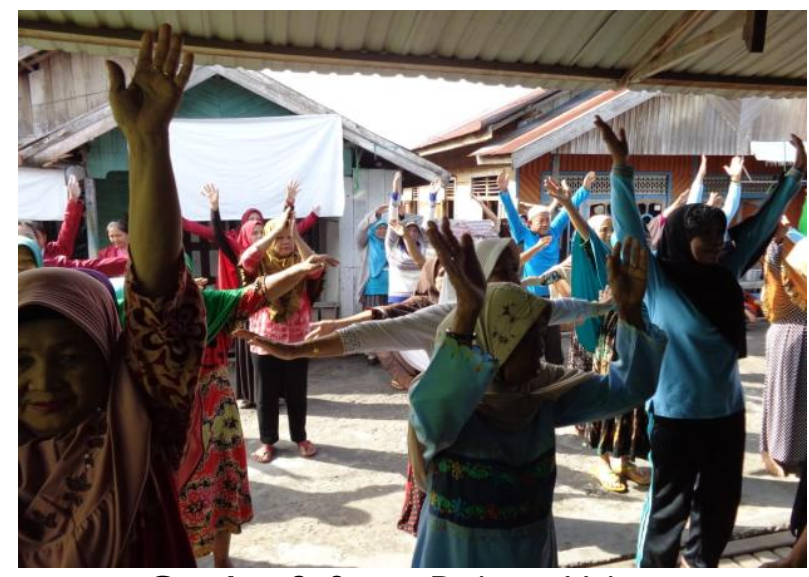

Gambar 2. Senam Diabetes Melitus

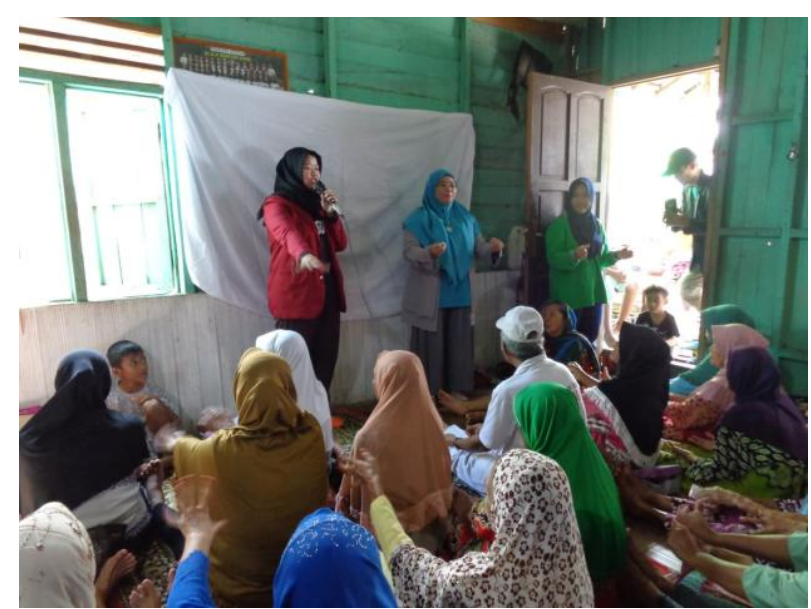

Gambar 3. Praktik Relaksasi Benson

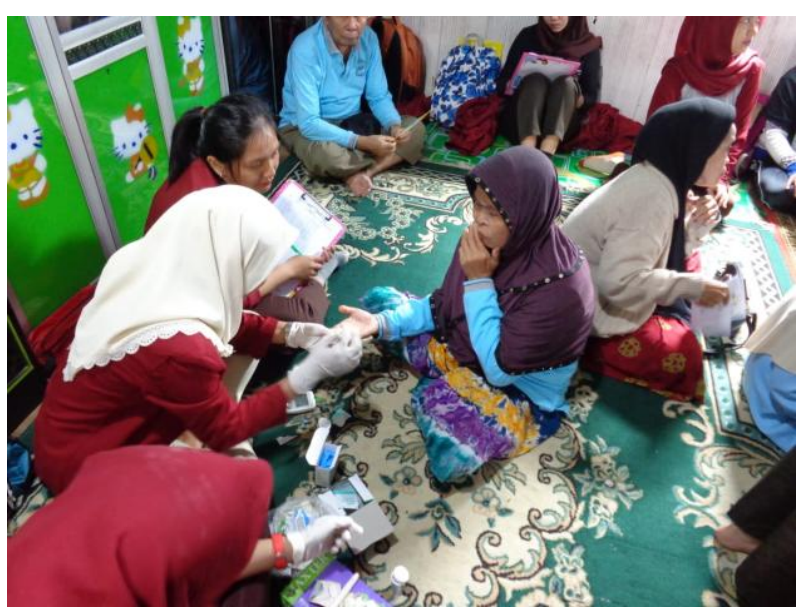

Gambar 4. Pemeriksaan Gula Darah Sewaktu

\section{KESIMPULAN}

Kegiatan pencegahan sekunder diabetes melitus melalui pendidikan kesehatan tentang diabetes melitus dan penatalaksaan Relaksasi Benson sangat bermanfaat untuk meningkatkan kualitas hidup penderita diabetes melitus. Kegiatan ini memberikan peningkatan pengetahuan dan keterampilan tentang diabetes melitus dan cara menurunkan kadar gula darah melalui Relaksasi Benson. Kegiatan ini dapat dilakukan secara berkesinambungan sebagai upaya pencegahan sekunder untuk mencegah komplikasi penderita diabetes.

\section{UCAPAN TERIMA KASIH}

Penulis mengucapkan terimakasih kepada Poltekkes Kemenkes Palangka Raya dan Badan PPSDM yang telah memberi bantuan dana dalam kegiatan pengabdian masyarakat ini, Pembimbing Klinik dari Puskesmas Pahandut, Mahasiswa Program Studi Diploma IV Keperawatan dan Para Kader Posyandu Eka Harapan Wilayah Kerja Puskesmas Pahandut Palangka Raya yang telah membantu dalam pelaksanaan kegiatan pengabdian masyarakat.

\section{REFERENSI}

Badan Pusat Statistik Kalimantan Tengah. 2016. Jumlah kasus terbanyak di provinsi Kalimantan Tengah. (http://kalteng.bps.go.id/staticable/2017/07/I 
9/466/jumlah-kasus- I0-penyakit-terbanyakdi-provinsi-kalimantan-tengah-20l6.html)

Benson, H. \& Proctor, W. 2000. Dasar-Dasar Respon Relaksasi: Bagaimana Menggabungkan Respons Relaksasi Dengan Keyakinan Pribadi Anda. Alih bahasa oleh Nurhasan. Bandung: Kaifa.

Datak, G., Yetti, K., \& Hatiyati, R.T.S. 2008. Penurunan Nyeri Pascabedah Pasien TUR Prostat Melalui Relaksasi Benson. Jurnal Keperawatan Indonesia. 12(3): I73-178.

Dinas Kesehatan Provinsi Kalimantan Tengah. 2015. Jumlah Kasus 10 Penyakit Terbanyak di Provinsi Kalimantan Tengah. (http://bappeda.kalteng.go.id/satudata/tabel/in dex/I09/back_2)

Kuswandi, A., Sitorus, R., Gayatri, D. 2008. Pengaruh Relaksasi Terhadap Penurunan Kadar Gula Darah Pada Pasien Diabetes Mellitus Tipe 2 di Sebuah Rumah Sakit di Tasikmalaya. Jurnal Keperawatan Indonesia. I2(2): I08-II4.

International Diabetes Federation. 2015. Diabetes Atlas, $7^{\text {th }}$ Edition. (http://www.idf.org/diabetesatlas)

Purwasih, E.O., Permana, I., \& Primanda, Y. 2017. Relaksasi Benson dan Terapi Murottal Surat Ar-Rahmaan Menurunkan Kadar Glukosa Darah Puasa Pada Penderita Diabetes Melitus Tipe 2 Di Kecamatan Maos. Jurnal Ilmiah Kesehatan Keperawatan. 13(2):69-73.

Putri, N.H.K. \& Isfandiari, M.A. 20I3. Hubungan Empat Pilar Pengendalian DM Tipe 2 dengan Rerata Kadar Gula Darah. Jurnal Berkala Epidemiologi. I(2):234-243.

Rasubala, G.F., Kumaay, L.T., \& Mulyadi. 2017. Pengaruh teknik relaksasi benson terhadap skala nyeri pada pasien post operasi di RSUP Prof. DR. R.D. Kandou dan RS TK. III R.W. Mongisidi Teling Manado. Jurnal Keperawatan. 5(I): I- I0.

Smeltzer, S.C. \& Bare, B.G. 2002. Buku Ajar Keperawatan Medikal Bedah Brunner \& Suddarth Edisi 8, Volume 2. Jakarta: EGC.

Smeltzer, S., Bare, B., Hinkle, J., \& Cheever, K. 2008. Brunner and Suddarth's textbook of medicalsurgical nursing (I/th ed.). Philadelphia: Lippincott Williams \& Wilkins.

Solehati, T. \& Kosasih, C.E. 20I5. Konsep \& Aplikasi Relaksasi Dalam Keperawatan Maternitas. Bandung: Refika Aditama.
World Health Organization. 2016. Global Resort on Diabetes.

(http://apps.who.int/iris/bitstream/10665/204 87I/ //978924 I 565257_eng.pdf?ua= I)

Wulandari, M.Y. \& Isfandiari, M.A. 20I3. Kaitan Sindroma Metabolik dan Gaya Hidup Dengan Gejala Komplikasi Mikrovaskuler. Jurnal Berkala Epidemiologi. I (2):224-233.

Yusliana, A., Misrawati, \& Safri. 20I5. Efektifitas relaksasi benson terhadap penurunan nyeri ibu postpartum sectio caesarea. Jurnal Online Mahasiswa Program Studi Ilmu Keperawatan Universitas Riau. 2(2):944-952. 